\title{
Autosomal recessive limb-girdle muscular dystrophy type 2J
}

INSERM

\section{Source}

INSERM. (1999). Orphanet: an online rare disease and orphan drug data base. Autosomal recessive limb-girdle muscular dystrophy type 21. ORPHA:140922

Autosomal recessive limb-girdle muscular dystrophy type 2J (LGMD2J) is a form of limbgirdle muscular dystrophy that usually has a childhood onset (but can range from the first to third decade of life) of severe progressive proximal weakness, eventually involving the distal muscles. Some patients may remain ambulatory but most are wheelchair dependant 20 years after onset. 